\title{
Trakya Bölgesi'nde hasat edilmiş kanola (Brassica napus L.) tohumlarında tohum kökenli fungal etmenlerin tespiti ${ }^{1}$
}

\author{
Didar ALPASLAN ${ }^{2}$
}

\author{
$\underline{\text { Nuray ÖZER }}^{3}$
}

\begin{abstract}
Determination of seed-borne fungal pathogens on harvested canola (Brassica napus $\mathbf{L}$.) seeds from Thrace Region
\end{abstract}

The aim of this study was to determine fungal pathogens on seed samples of canola collected in 2013 from the fields located on Edirne, Tekirdağ, Kırklareli provinces of Thrace region, and their pathogenicity. Additionally, the cultural and morphological characteristics of fungal species, which were highly pathogenic, were determined. As a result of the study, it was found that seed samples collected from Thrace region of Turkey were contaminated with A. alternata in the alternata species groups of Alternaria genus at the highest rate, A. ethzedia and A. infectoria in the infectoria species groups of the same genus followed it. Other species detected in canola seed samples were Arthrinium arundinis, Cladosporium sp., Curvularia sp., Fusarium sp., Phomopsis sp. and the most common species of these was A. arundinis. In the result of pathogenicity tests, A. alternata isolates caused disease severity between $52.2-76 \%$ on seedling; the isolates of A. ethzedia had virulence capacity ranged from 31.5 to $82 \%$. This range was between $24.7-70.5 \%$ for $A$. infectoria and between 56.20-69.20\% for A. arundinis.

Keywords: Canola (Brassica napus L.), seed-borne fungi, pathogenicity

\section{ÖZ}

Bu çalışmada 2013 yılında Trakya Bölgesi'nde bulunan Edirne, Kırklareli ve Tekirdağ illerinden toplanan kanola tohumu örneklerinde fungal etmenlerin tespiti ve patojenisitelerinin belirlenmesi amaçlanmıştır. Çalışmada ayrıca yüksek derecede patojen

1 Bu çalışma Namık Kemal Üniversitesi Bilimsel Araştırma Fonu tarafından NKUBAP.00.24.YL.13.10 no. lu proje ile desteklenmiş Yüksek Lisans tezinin bir bölümüdür. Çalışma ayrıca 9-11 Eylül 2015 tarihinde İstanbul'da düzenlenen 2. Ulusal Mikoloji Günleri Sempozyumunda poster olarak sunulmuş ve özet olarak basılmıştır.

${ }^{2}$ T.C. Gıda Tarım ve Hayvancılık Bakanlığı, Ağrı Zirai Karantina Müdürlüğü. Doğubeyazıt/Ağrı

${ }^{3}$ Namık Kemal Üniversitesi, Ziraat Fakültesi, Bitki Koruma Bölümü, Tekirdağ

Sorumlu yazar (Corresponding author) e-mail: nurayozer62@gmail.com

Alını̧̧ (Received): 30.01.2017, Kabul ediliş (Accepted): 20.03.2017 
bulunan fungus türlerinin kültürel ve morfolojik özellikleri tanımlanmıştır. Çalışma sonucunda Trakya Bölgesi'ndeki illere ait tohum örneklerinde yapılan incelemelerde tohumların en yüksek oranda Alternaria cinsi içindeki alternata türleri grubundan $A$. alternata ile bulaşık olduğu, bunu infectoria türleri grubundan A. ethzedia ve $A$. infectoria'nın izlediği belirlenmiştir. Tohum örneklerinde tespit edilen diğer funguslar ise Arthrinium arundinis, Cladosporium sp., Curvularia sp., Fusarium sp., ve Phomopsis sp. olarak tanımlanmış olup, bunlar arasında en yaygın türün $A$. arundinis olduğu görülmüştür. Fungal etmenlerle yapilan patojenisite testleri sonucunda, A. alternata izolatları \%52.2\%76.0, A. ethzedia izolatları \%31.5-\%82, A. infectoria izolatlar1 \%24.7-\%70.5 ve A. arundinis izolatları \%56.20-\%69.20 arasında değişen oranlarda hastalık şiddeti oluşturmuşlardır.

Anahtar kelimeler: Kanola (Brassica napus L.), tohum kökenli funguslar, patojenisite

\section{Gíriș}

Tohumlarından elde edilen yağı insan, yüksek protein içeren küspesi hayvan beslenmesinde ve biyodizel üretiminde kullanılabilen bir bitki olan kanola ülkemizde ve dünyada artan yağlı tohumlu bitki ihtiyacını karşlayabilecek potansiyelde bir bitki olma özelliği taşımaktadır. Ülkemizde Güneydoğu, Kuzeydoğu, Ortadoğu Anadolu ve Doğu Karadeniz Bölgesi dişındaki tüm bölgelerde kanola üretimi yapılmaktadır. Üretimi yapılan bölgeler arasında 2015 y1lı TÜİK verilerine göre 294.921 da üretim alanı ve 99.132 ton üretimle Bat1 Marmara Bölgesi ilk sırayı almaktadır. Bölge içinde ise Tekirdăg, Kırklareli ve Edirne illeri toplam 260.420 da üretim alanı ve 87.954 ton üretimle önemli bir yer tutmaktadır (Anonim 2017). Bölgede kanola üretimi, 1997 yllında ilk önce Tekirdağ ilinde başlamış, bunu 2002 yılında Kırklareli ve 2007 yılında Edirne takip etmiştir. Her üç ilde son beş yıllık verim değerlerine bakıldığında verimde zaman zaman düşüşler olduğu görülmüştür. Verim azalmalarındaki en önemli etkenlerden birisinin hastalık ve zararlılar olduğu bilinen bir gerçektir.

Dünya çapında değerli bir endüstri bitkisi olarak önemli yere sahip yağlı tohumlu bir bitki olan kanolanın, fungal hastalık etmenleri için elverişli bir ortam sunduğu, bu hastalık etmenlerinin başında Alternaria spp. ve Phoma lingam gelmekle birlikte, tohum kökenli fungal patojenlerin kanolada önemli verim kayılarına yol açtı̆̆ 1 belirtilmektedir (Brazauskiene and Petraitiene 2006). Yurt dışında kanolada tohum kökenli fungal hastalık etmenleri konusunda yapılmış çalışmalarda Alternaria alternata, A. brassicae, A. raphani, Arthrinium phaeospermum, Aspergillus flavus, A. glaucus, Cladosporium cladosporioides, Fusarium acuminatum, F. avenaceum, F. dimerum, F. equiseti, Phoma lingam, Stemphylium vesicarium ve $S$. herbarum'un varllğ 1 tespit edilmiş ve bunlar arasında en yaygın türün $A$. alternata olduğu bunu $A$. brassicae ve $A$. raphani'nin takip ettiği bildirilmiştir (Clear 1992, Visconti et al. 1992, Vinas et al. 1994, Clear and Patrick 1995, Chen et al. 2010, Meena et al. 2010, Mankeviciene et al. 2011). Söz konusu fungus türleri arasında $P$. lingam ile gerçekleştirilen patojenisite testlerinde etmenin yüksek derecede virülent olduğu belirtilmektedir (Clear 1992). 
Kanola tohumlarında izole edilen fungus türlerinden çoğunun toksin üretme yeteneğinde olması tohumluk açısından büyük risk taşımaktadır. Yapılan çalışmalarda kanola tohumlarından izole edilen A. alternata izolatlarının tenuazonik asit, alternariol, alternariol mortometil eter, altertoksin I ve II'yi üretebildiği ve tenuazonik asit içeren izolatların kanolada fide gelişimini engellediği tespit edilmiştir (Visconti et al. 1992). Yine kanolada Fusarium spp. 'nin ürettikleri toksinlerden deoksinivalenol (DON), zearalenone (ZEA) ve T2 toksinlerinin varlığı belirlenmiştir (Mankeviciene et al. 2011).

Kanolada tohumla taşınan hastalık etmenlerinin belirlenmesine yönelik olarak ülkemizde yapılmış bir araştırma ile karşılaşılmamıştır. Bununla birlikte yaprak ve gövde hastalıkları ile ilgili tespitler bulunmaktadır. Çanakkale ilinde kışlık kanola çeşitlerinin tohum ve tohum kalitesi konusunda yapılan bir çalışmada en yaygın olarak külleme hastalığına rastlandığı bildirilmektedir (Gül ve ark. 2005). Son yıllarda Trakya Bölgesi'nde kanola ekiliş alanlarının Phoma lingam ile yüksek oranda bulaşık olduğu, hastalığın rozet döneminde yaprak lekeleri, olgunluk döneminde sap leke ve kanser yaraları şeklinde kendini gösterdiği bildirilmektedir (Damgacı ve Yılmaz 2016). Araştırmacılar ayrıca etmenin \%18.8-27.3 oranlarında kapsül azalmasına neden olduğunu, ancak yan dal sayısı ve kapsüldeki tane sayısı açısından hasta ve kontrol bitkiler arasında önemli bir farklılığın olmadığını belirtmektedirler.

$\mathrm{Bu}$ çalışmada Trakya bölgesinde yaygın olarak kanola ekimi yapılan illerden alınan tohum örneklerinde görülen fungal etmenlerin belirlenmesi, tanılanması ve patojenisitelerinin ortaya çıkarılması amaçlanmıştır.

\section{MATERYAL VE METOT}

Bu araştırmada, materyal olarak 2013 yılında Trakya Bölgesi'ndeki illerde kanola yetiştirilen tarlalardan toplanan tohum örnekleri kullanılmıştır.

\section{Tohum örneklerinin toplanması ve fungal izolasyon}

Trakya Bölgesi'ndeki tohum örnekleri 2013 yılında Edirne, Kırklareli ve Tekirdağ illerine ait ekiliş alanları dikkate alınarak toplanmıştır. Trakya Bölgesi kanola ekim alanlarından alınan örneklerin dağılımı Çizelge 1'de verilmiştir. Örnekleme sırasında tarlanın köşegenleri boyunca tohum örnekleri alınmış, paçal inceleme yapmak üzere laboratuvara getirilmiştir.

Fungal izolasyon için tohumlar \%1'lik $\mathrm{NaOCl}$ (sodyum hipoklorit) ile 5 dakika süreyle yüzey dezenfeksiyonu yapılmış, daha sonra $3 \mathrm{kez}$ steril destile su ile yıkanarak steril kurutma kağıtları arasında kurutulmuş ve PDA (Potato Dextrose Agar) besi ortamına yerleştirilmiştir. Tohum örnekleri $25^{\circ} \mathrm{C}$ 'de bir hafta süreyle inkübe edilmiş, inkübasyon süresi sonrasında tohumlar üzerinde gelişen funguslar, koloni gelişimleri ve morfolojik özellikleri dikkate alınarak gruplandırılmış ve tek spor izolasyonları yapılmıştır. 
Trakya Bölgesi'nde hasat edilmiş kanola (Brassica napus L.) tohumlarında tohum kökenli fungal etmenlerin tespiti

Çizelge 1. Trakya Bölgesi kanola ekim alanlarından alınan örneklerin dağılımı

\begin{tabular}{|l|c|l|c|}
\hline Örnek alınan il & Ekiliş alanı (da) & \multicolumn{1}{|c|}{ İçeler } & $\begin{array}{c}\text { Örnek alınan tarla } \\
\text { sayısı }\end{array}$ \\
\hline Edirne & \multirow{2}{*}{17.058} & Havsa & 2 \\
& & Lalapaşa & 3 \\
& & Merkez & 3 \\
\hline Kırklareli & 22.848 & Babaeski & 3 \\
& & Lüleburgaz & 3 \\
& & Merkez & 2 \\
\hline Tekirdağ & \multirow{2}{*}{220.520} & Corlu & 3 \\
& & Hayrabolu & 3 \\
& & Malkara & 1 \\
& & Marmara Ereğlisi & 3 \\
& & Merkez & 3 \\
& & Muratlı & 3 \\
\hline
\end{tabular}

Fungus kültürleri, daha sonraki testlerde kullanılmak üzere PDA içeren eğik agarda $+4{ }^{\circ} \mathrm{C}$ 'de buzdolabında saklanmışlardır. Tohumlarda Phoma lingam' 1 tespit etmek için Chen et al. (2010) tarafından önerilen ilave bir test uygulanmıştır. Bu amaçla 1 $\mathrm{g}$ tohum su içinde 12 saat süre ile $4{ }^{\circ} \mathrm{C}$ 'de bekletilmiş, bu süre sonunda sudan alınarak $-20^{\circ} \mathrm{C}^{\prime}$ de 24 saat bekletilmiştir. Bu süre sonunda yukarıda belirtildiği gibi yüzey sterilizasyonu yapılmış ve PDA besi ortamında $20{ }^{\circ} \mathrm{C}^{\prime} \mathrm{de}$ karanlıkta inkübasyona bırakılmışlardır. Denemeler her petride 20 adet tohum olacak şekilde 10 tekrarlı olarak yürütülmüştür.

\section{Patojenisite testleri}

Patojenisite testlerinde morfolojik ve kültürel gelişmelerine göre ayrilan gruplardan her ilçeyi temsil edecek şekilde tesadüfi olarak seçilen izolatlar kullanılmıştır. Tek spor izolasyonu yapılan izolatlar spor süspansiyonu hazırlanarak tohumlara inokule edilmiş, spor üretmeyen grupların inokulasyonunda ise agar diski yöntemi uygulanmıştır. Söz konusu testlerde Alternaria spp. ye ait izolatlarda $1 \times 10^{5}$ konidi/ml (Tohyama and Tsuda 1995, Perello et al. 2008, Noelting et al. 2012), Arthrinium sp. ye ait izolatlar için $1 \times 10^{6}$ konidi/ml (Grey and Sands 1992) yoğunlukları kullanılmıştır. Konidi üretmeyen izolatların patojenisitelerinin belirlenmesinde ise, 7 günlük fungus kültürlerinden mantar delici yardımıyla 0.4 $\mathrm{cm}$ diskler hazırlanmış (Oviedo et al. 2011), spor süspansiyonu inokulasyonu yönteminde belirtildiği gibi kurutma kağıtları üzerine yerleştirilen her bir tohumun üzerine 1 adet disk yerleştirilmiştir.

Her iki yöntemde de denemeler her bir petride 20 tohum olacak şekilde 5 tekrarlı olarak yürütülmüştür. İnokule edilmiş tohumlar $23{ }^{\circ} \mathrm{C}^{\prime}$ deki inkübatöre yerleştirilerek 1 hafta sonunda izolatların patojenisiteleri belirlenmiştir. Fidecikler üzerinde farklı şekilde belirtiler gözlenmesi nedeniyle tarafımızdan oluşturulan 0-4 skalası (0: Sağlıklı, 1: Çimlenme var, kökler fungus tarafindan kolonize olmuş, 
yaprakta leke yok, 2: Kök gelişimi az, yapraklarda lekeler var, 3: Çimlenme var, çimlenme sonrası çim bitkisi kahverengileşerek ölmüş, 4: Çimlenme yok, tohumlar fungus tarafindan tamamen kolonize olmuş) ile bitkiler değerlendirilmiş ve Townsend-Heuberger formülü kullanılarak hastalık şiddetleri hesaplanmıştır (Karman 1970).

\section{Fungus türlerinin tanılanması}

Çalışmamızda hem yüksek oranda izole edilen hem de patojenisite testlerine en yüksek oranda hastalık şiddeti oranı gösteren izolatların PDA, PCA (Potato Carrot Agar) ve MEA (Malt Extract Agar) besi ortamları üzerinde koloni gelişimleri (koloni rengi, gelişme hızı), morfolojik özellikleri (konidiofor ve konidi şekli, konidi büyüklükleri) belirlenmiştir (Ellis 1976, Domsch et al. 1980, Watanabe 2002, Woudenberg et al. 2013, Lawrence et al. 2014). Farklı besi ortamlarında gelişme hızlarının belirlenmesi çalışması her bir türden $0.8 \mathrm{~cm}$ 'lik agar diskleri kullanılarak 4 tekrarlı olarak yürütülmüştür. Ayrıca genomik DNA ekstraksiyonu, PCR amplifikasyonu ve DNA dizi analizi için izolatlar REFGEN firmasına gönderilmiş ve DNA dizilimi sonuçları alınmıştır. Her bir türe ait DNA dizilimleri BLAST'lama yapılarak tür teşhisleri gerçekleştirilmiştir.

\section{İstatistiksel analiz}

Çalışmamızda patojenisite testleri sonucunda elde edilen değerler ve gelişme hızı verileri varyans analizine tabii tutulmuş, ortalamalar arasındaki farklılıklar Duncan Çoklu Karşılaştırma Testine göre $(\mathrm{P}=0.05)$ belirlenmiştir.

\section{SONUÇLAR VE TARTIŞMA}

Son yıllarda Alternaria türleri birbirlerine genetik olarak çok benzeyen farklı tür gruplarını içeren 24 farklı seksiyonda tanımlanmaktadır (Woudenberg et al. 2013, Lawrence et al. 2013, Lawrence et al. 2014). Bu nedenle bu çalışmada bu tür grupları dikkate alınarak sonuçlar sunulmuştur.

\section{Kanola tohum örneklerinde tespit edilen funguslar ve bulaşık tohum oranları}

Trakya Bölgesi'nden alınan tohum örneklerinde 3 adet Alternaria türü 1 adet Arthrinium türü, ayrıca Cladosporium, Curvularia, Fusarium ve Phomopsis cinsine rastlanmıştır (Çizelge 2). Alternaria türleri arasında, alternata tür grubundan $A$. alternata, infectoria tür grubundan $A$. ethzedia ve A. infectoria her üç ile ait tohumlarda rastlanmış, enfekteli tohum oranı açısından A. alternata ilk sırayı almıştır. Arthrinium arundinis özellikle Kırklareli iline ait tohumlarda daha yüksek oranda bulunmuştur. Cladosporium sp., Curvularia sp., Fusarium sp. ve Phomopsis sp. ise genelde düşük oranlarda tespit edilmişlerdir. Farklı fungus türleri ile bulaşık toplam tohum oranı dikkate alındığında ise Kırklareli ilinin \%38.52 ile ilk sırayı aldığı, çok yakın bir oranla (\%38.3) bunu Edirne ilinin izlediği, Tekirdağ iline ait örneklerin ise toplam bulaşıklılık oranı yönünden son sırada (\%20.6) yer aldığı görülmüştür. 
Trakya Bölgesi'nde hasat edilmiş kanola (Brassica napus L.) tohumlarında tohum kökenli fungal etmenlerin tespiti

Çizelge 2. Trakya Bölgesi illerine ait tohum örneklerinde fungal etmenlerle enfekteli tohum oranları

\begin{tabular}{|l|c|c|c|}
\hline \multirow{2}{*}{ Fungus türü } & \multicolumn{3}{c|}{ Enfekteli tohum oranı (\%) } \\
\cline { 2 - 4 } & Edirne & Kırklareli & Tekirdă \\
\hline Alternaria alternata $*$ & 27.60 & 24.20 & 14.00 \\
\hline Alternaria ethzedia $* *$ & 7.60 & 4.80 & 4.46 \\
\hline Alternaria infectoria $* *$ & 2.30 & 4.40 & 1.56 \\
\hline Arthrinium arundinis & 0.50 & 4.20 & 0.50 \\
\hline Cladosporium sp. & 0.12 & 0.80 & 0.03 \\
\hline Curvularia sp. & 0.12 & 0.00 & 0.03 \\
\hline Fusarium sp. & 0.00 & 0.12 & 0.03 \\
\hline Phomopsis sp. & 0.06 & 0.00 & 0.00 \\
\hline Toplam & 38.30 & 38.52 & 20.60 \\
\hline alternata tür grubu ** infectoria tür grubu
\end{tabular}

İncelenen tohumlarda en yaygın tür olarak belirlenen A. alternata, farklı ülkelerde incelenen kanola tohumlarında da en yaygın fungus türü olarak bildirilmektedir (Visconti et al. 1992, Vinas et al. 1994, Clear ve Patrick 1995). Bazı çalışmalarda yaygın Alternaria türü olarak bildirilen A. brassicae, A. raphani'ye ise (Clear 1992, Clear and Patrick 1995, Meena et al. 2010) tohum örneklerinde rastlanmamıştır. Araştırmamızda incelenen tohum örneklerinde, fungus türleri ile bulaşıklık dikkate alındığında A. alternata'yı, A. ethzedia ve A. infectoria izlemiştir. Söz konusu türler her üç ile ait tohum örneklerinde bulunmuşlardır. Dış ülkelerde daha önce yapılan çalışmalarda A. ethzedia kanolada (Woudenberg et al. 2013), A. infectoria buğday, arpa, yulaf, yem bitkileri ve horozibiği tohumlarında bulunmuştur (Dugan and Lupien 2002, Kosiak et al. 2004, Gannibal 2008, Perello et al. 2008, Noelting et al. 2012, Perello and Larran 2013). Ülkemizde ise kimyonda solgunluk, çökerten, kök çürüklügü ve yaprak lekeleri gösteren bitkilerden A. infectoria tespit edilmiştir (Özer ve Bayraktar 2015). Her üç ile ait tohumlardan izole edilen Arthrinium arundinis ise bugüne kadar sadece arpa tohumlarından izole edilmiştir (Grey and Sands 1992). Bu çalışmada bölge tohumlarından düşük oranlarda izole edilen Cladosporium sp., Curvularia sp., Fusarium sp. ve Penicillium sp. fungusları diğer ülkelerde de düşük oranlarda kanola tohumlarında tespit edilmiştir (Vinas et al. 1994, Clear and Patrick 1995, Mankeviciene et al. 2011).

Dış ülkelerde kanolanın en önemli hastalıkları arasında belirtilen ve tohumla taşındığı tespit edilen Phoma lingam'a ise, farklı araştırıcılar tarafindan önerilen izolasyon yöntemleri kullanılarak izole edilmeye çalışılmış olmasına rağmen, yapılan araştırmalarda incelenen tohumlarda bu türün tespit edildiğine dair bir kayıt bulunmamaktadır (Clear 1992, Clear and Patrick 1995, Brazauskiene and Petraitiene 2006, Chen et al. 2010).

\section{İzole edilen fungusların patojenisiteleri}

En yüksek oranda izole edilen fungus türü olan A. alternata'ya ait tüm izolatlar $\% 50$ 'nin üzerinde hastalık şiddeti meydana getirmiştir (Çizelge 3). Bununla birlikte 
Kırklareli/Merkez ilçeden alınan 32.3 nolu izolat en yüksek oranda (Şekil 1), Tekirdağ Marmara Ereğlisi'nden alınan 30.23 nolu izolat ise en düşük oranda hastalık şiddeti oluşturmuştur. Çalışmamızda her ile ait örneklerde yüksek derecede patojen olan izolatların var olduğu görülmüştür.

Çizelge 3. Alternaria alternata izolatlarının kanolada oluşturdukları hastalık şiddeti

\begin{tabular}{|c|c|c|}
\hline Izolat No & Alındığı yer & Hastalık şiddeti (\%)* \\
\hline 3.9 & Edirne/Merkez & $64.00 \pm 4.13 \mathrm{abcd}$ \\
\hline 7.5 & Edirne/Havsa & $55.20 \pm 4.86 \mathrm{de}$ \\
\hline 4.11 & Edirne/Lalapaşa & $73.50 \pm 3.22 \mathrm{ab}$ \\
\hline 12.5 & Kirklareli/Babaeski & $68.00 \pm 5.95 \mathrm{abc}$ \\
\hline 11.8 & Kirklareli/Lüleburgaz & $64.50 \pm 3.50 \mathrm{abcd}$ \\
\hline 32.3 & Kirklareli/Merkez & $76.00 \pm 3.76 \mathrm{a}$ \\
\hline 24.5 & Tekirdağ/Çorlu & $68.00 \pm 2.58 \mathrm{abc}$ \\
\hline 18.20 & Tekirdağ/Hayrabolu & $66.00 \pm 1.99 \mathrm{abcd}$ \\
\hline 20.15 & Tekirdă̆/Malkara & $56.50 \pm 2.78 \mathrm{cde}$ \\
\hline 30.23 & Tekirdağ/M. Ereğlisi & $52.20 \pm 2.54 \mathrm{e}$ \\
\hline 23.5 & Tekirdă̆/Merkez & $61.50 \pm 2.97 \mathrm{bcde}$ \\
\hline 16.2 & Tekirdă̆/Muratlı & $71.70 \pm 3.74 \mathrm{ab}$ \\
\hline
\end{tabular}

*Her değer 20 tohum içeren 5 tekrarın ortalamasıdır. Birbirinden farklı harflerle gösterilen değerler Duncan Çoklu Karşılaştırma testine göre birbirinden önemli derecede farklıdır ( $(\mathrm{P}=0.05)$
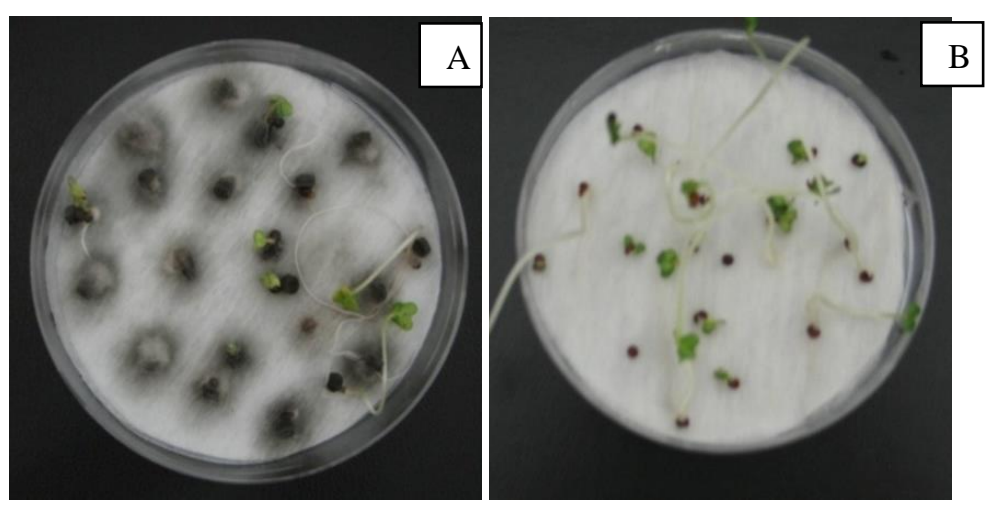

Şekil 1. Alternaria alternata'nın tohumlar üzerinde oluşturduğu hastalık şiddeti (A: İnokule edilmiş tohumlar, B: Kontrol)

A. arundinis ile yapılan testlerde 4 izolat kullanılmış, izolatların oluşturdukları hastalık şiddetleri arasında istatistiki olarak önemli derecede bir farklılık olmadığ 1 görülmüştür (Çizelge 4).

Çizelge 4. Arthrinium arundinis izolatlarının kanolada oluşturdukları hastalık şiddeti

\begin{tabular}{|c|c|c|}
\hline İzolat No & Alındığı yer & Hastalık şiddeti (\%)* \\
\hline 7.1 & Edirne/Havsa & $64.00 \pm 4.35 \mathrm{a}$ \\
\hline 10.7 & Kırklareli/Lüleburgaz & $56.20 \pm 5.84 \mathrm{a}$ \\
\hline 25.1 & Tekirdağ/Çorlu & $58.70 \pm 2.59 \mathrm{a}$ \\
\hline 18.1 & Tekirdağ/Hayrabolu & $69.20 \pm 3.12 \mathrm{a}$ \\
\hline
\end{tabular}

*Her değer 20 tohum içeren 5 tekrarın ortalamasıdır. Birbirinden farklı harflerle gösterilen değerler Duncan Çoklu Karşılaştırma testine göre birbirinden önemli derecede farklıdır ( $(\mathrm{P}=0.05)$ 
Bununla birlikte tüm izolatlar \%50'nin üzerinde patojen bulunmuştur. En yüksek hastalık şiddeti ise \%69.2 ile 18.1 nolu izolatla elde edilmiştir. Çok düşük oranda izole edilmeleri ve tür teşhislerinin tamamlanmaması nedeniyle Curvularia sp., Cladosporium sp. ve Fusarium sp.'ye ait izolatların patojenisite testi sonuçları verilmemiştir.

Kanolada A. alternata ile ilgili yapılan çalışmalar daha ziyade fungusun tarlada oluşturduğu hastalık şiddeti ve tohumlarda tespitine yöneliktir. Bu nedenle bu çalışmada tespit edilen fungus türlerinin kanola tohumlarındaki patojenisiteleri ilk kez belirlenmiştir. Çalışmamızda patojenisitelerin izolatlara göre farklılık gösterdiği tespit edilmiştir. Daha önceki yıllarda A. infectoria ile buğday tohumlarında yapılan patojenisite testlerinde etmenin patojen olduğu (Perello et al. 2008), buğday fideciklerinde enfeksiyona neden olduğu belirlenmiştir (Perello and Larran 2013). Horozibiği tohumlarında ise bodur ve şişkin kök oluşumuna neden olduğu bildirilmektedir (Noelting et al. 2012). Bununla birlikte kimyon bitkisinde yapılan patojenisite testlerinde ise zayıf patojen olarak belirtilmiştir (Özer ve Bayraktar 2015). Bu araştırmada söz konusu etmenle kanola tohumlarında yapılan patojenisite testlerinde fide enfeksiyonlarına rastlanmış \% 70 'e varan hastalık şiddeti yapabilen izolatların olduğu belirlenmiştir. Daha önce arpadan izole edilen A. arundinis' in ise arpalara sarı olum döneminde inokule edildiğinde danelerde renk değişikliğine neden olduğu bildirilmektedir (Grey and Sands 1992).

Alternaria cinsi içinde yer alan infectoria tür grubundan A. ethzedia izolatlarının patojenisiteleri incelendiğinde (Çizelge 5) izolatların çoğunun \%70'in üzerinde hastalık şiddeti oluşturduğu tespit edilmiştir. İzolatlar arasında en yüksek hastalık şiddeti (\%82), Tekirdağ Merkez'e ait 17.18 nolu izolat tarafindan oluşturulmuş,

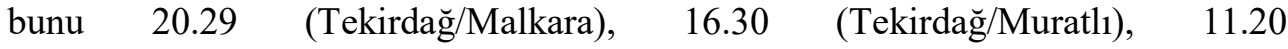
(Kırklareli/Lüleburgaz), 5.1 (Edirne/Lalapaşa), 14.7 (Kırklareli/Babaeski), 3.15 (Edirne/Merkez) nolu izolatlar izlemiştir.

Alternaria infectoria izolatları arasında ise en yüksek hastalık şiddeti \%70.5 ile 8.2 nolu izolat tarafından oluşturulmuş, bunu \%69.5 ile 29.2 nolu Tekirdağ izolatı izlemiştir (Çizelge 5). Diğer izolatlarla kıyaslandığında önemli derecede en düşük hastalık şiddetleri ise 16.27 (Muratl1), 18.2 (Hayrabolu), 18.2 (Babaeski) nolu izolatlar tarafindan meydana getirilmiştir. 


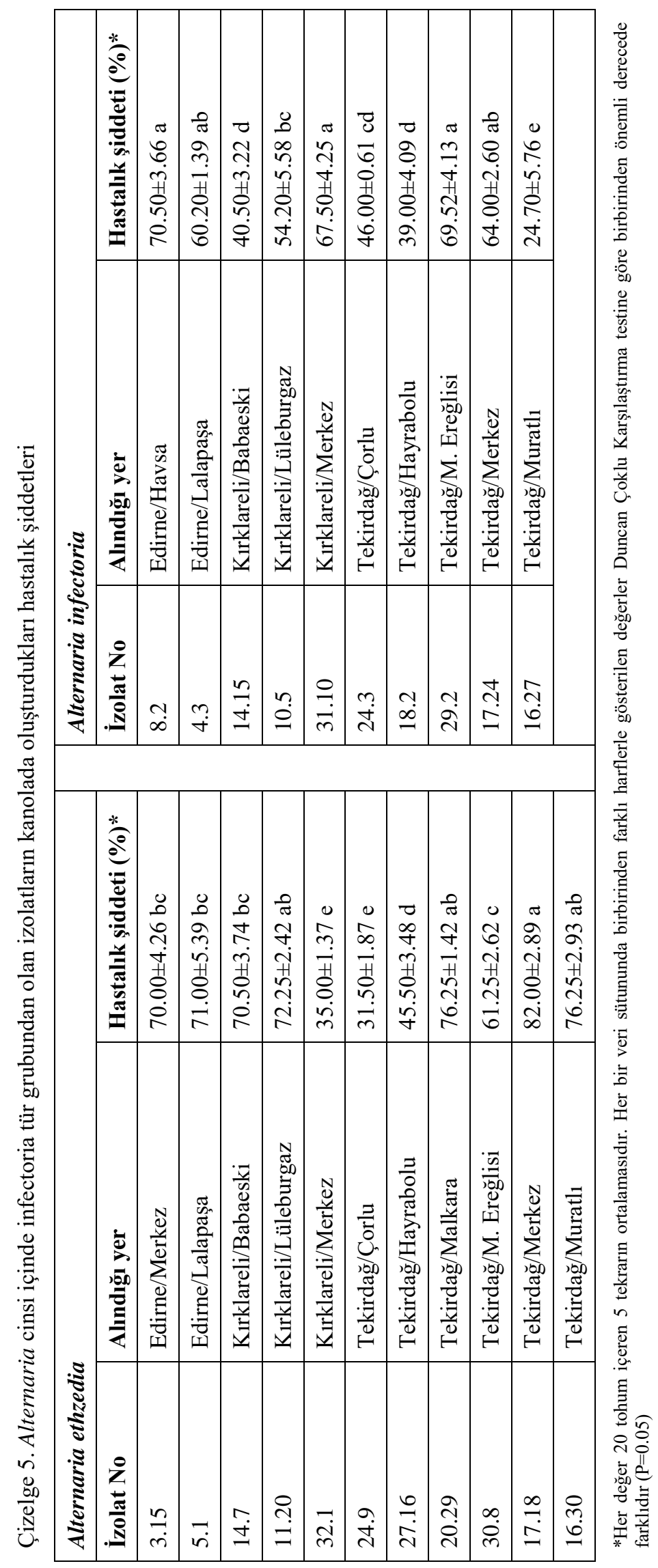




\section{Fungus türlerinin tanılanması}

$\mathrm{Bu}$ çalışmada, hem yüksek oranda bulunan hem de patojenisitesi yüksek olan ayrıca moleküler olarak gen dizilimlerine göre teşhis edilmiş olan A. alternata, A. ethzedia, A. infectoria ve Arthrinium arundinis'in farklı besi ortamlarındaki gelişimi, koloni rengi, konidi şekil ve büyüklükleri tanımlanmıştır.

Alternaria alternata (Fr.) Keissl PDA besi ortamında yeşilimtırak gri renkte açık yeşil zonlu olarak MEA besi ortamında alt kısmı koyu, üst kısmı daha açık renkli hiflerle kaplı olup, PCA besi ortamında ise hifsel gelişme göstermeden koyu renkli spor yığınları oluşturmuştur (Şekil 2A). 7 günlük inkübasyon sonucunda, gelişme hızları PDA besi ortamında $0.96 \mathrm{~cm} /$ gün, PCA besi ortamında $1.06 \mathrm{~cm} /$ gün, MEA besi ortamında ise $0.87 \mathrm{~cm} /$ gün olarak belirlenmiştir. Etmenin PCA besi ortamındaki gelişme hızı diğer ortamlardaki gelişme hızına göre önemli bulunmuştur $(\mathrm{P}=0.05)$. Etmenin konidileri enine ve boyuna bölmeli olup (Şekil 2B), boylar1 7.5-25.01 $\mu \mathrm{m}$ arasinda (Ortalama: 13.58 $\pm 2.42 \mu \mathrm{m}$ ) olup, enleri ise $6.17 \pm 0.94 \mu \mathrm{m}$ olarak belirlenmiş̧ir. Etmenin BLAST analizi Gen Bankasında bulunan çok sayıda A. alternata izolatı (Örnek Accession No: JF802090.1, JF835830.1, JF835832.1) ile \%99 oranında benzer olduğunu göstermiştir.

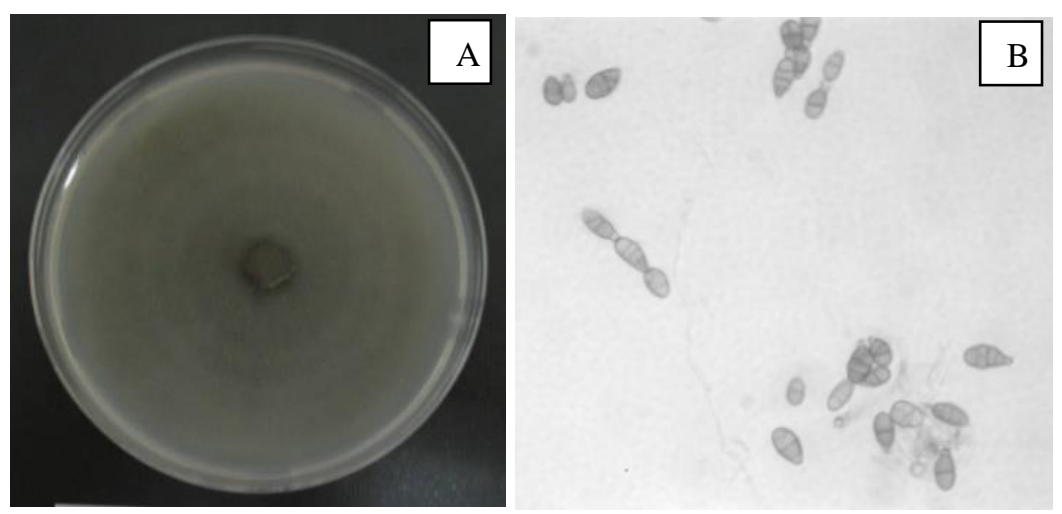

Şekil 2. Alternaria alternata'nın PCA besi ortamında koloni gelişimi (A) ve konidileri (B)

A. ethzedia E.G. Simmons (eşeyli formu: Lewia ethzedia E.G. Simmons) PDA besi ortamında (Şekil 3A) koyu zeytin yeşili renkte bir zemin üzerinde beyaz renkte, MEA (Şekil 3B) ve PCA besi ortamında ise beyaz renkte gelişmiştir. 7 günlük inkübasyon sonucunda, gelişme hızları PDA besi ortamında $0.87 \mathrm{~cm} /$ gün, PCA besi ortamında $0.81 \mathrm{~cm} /$ gün, MEA besi ortamında ise $0.70 \mathrm{~cm} /$ gün olarak belirlenmiştir. MEA'da gelişme hızı PDA besi ortamına göre önemli derecede yavaş olmuştur $(\mathrm{P}=0.05)$. Etmen hiçbir besi ortamında konidi oluşturmamıştır. Etmenin BLAST analizi sonucunda Gen Bankasında bulunan A. ethzedia izolatları [Accession No: AY278833.1, NR135928.1, KT281913.1: Bu izolatlarda kanoladan izole edilen A. ethzedia (AY278795, (Woudenberg et al. 2013) referans izolat olarak gösterilmektedir] ile \%99 oranında benzer bulunmuştur. 

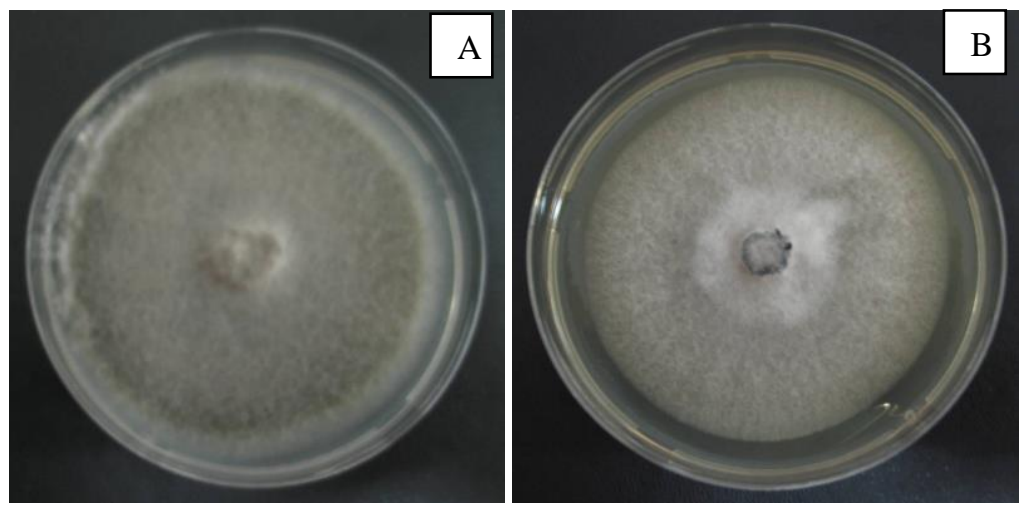

Şekil 3. Alternaria ethzedia'nın PDA (A) ve MEA (B) besi ortamında koloni gelişimleri

A. infectoria E.G. Simmons (eşeyli formu: Lewia infectoria (Fuckel) M.E. Barr \& E.G. Simmons), PDA besi ortamında zeytin yeşili renkte bir zemin üzerinde beyaz renkte pamuksu bir gelişme (Şekil 4A), MEA besi ortamında zemini koyu sarı üzeri kül renginde bir gelişme, PCA besi ortamında (Şekil 4B) ise zemin koyu üst kısmı seyrek hifsel bir gelişme göstermiş̧tir. 7 günlük inkübasyon sonucunda, gelişme hızları PDA besi ortamında $1.07 \mathrm{~cm} /$ gün, PCA besi ortamında 0.99 $\mathrm{cm} /$ gün, MEA besi ortamında ise $0.82 \mathrm{~cm} /$ gün olarak belirlenmiştir. PDA ve PCA ortamındaki hızlı gelişme önemli bulunmuştur $(\mathrm{P}=0.05)$. Etmenin konidileri uzun yumurtamsı ya da silindir yapısındadır. Uzunlamasına bölmeli konidiler kadar, uzunlamasına bölmesi olmayan konidiler de bulunmaktadır (Şekil 4C-F). Konidi boyları 30-42,5 $\mu \mathrm{m}$ (Ortalama: 37.46 \pm 2.42 ), enleri ise $9.63 \pm 1.40 \mu \mathrm{m}$ arasinda olmuştur. Etmen BLAST analizi sonucunda Gen Bankasında bulunan çok sayıda $A$. infectoria izolatlan (Örnek Accession No: KU516622.1, KT898619.1, KT692570.1) ile \%99 oranında benzer bulunmuştur. 


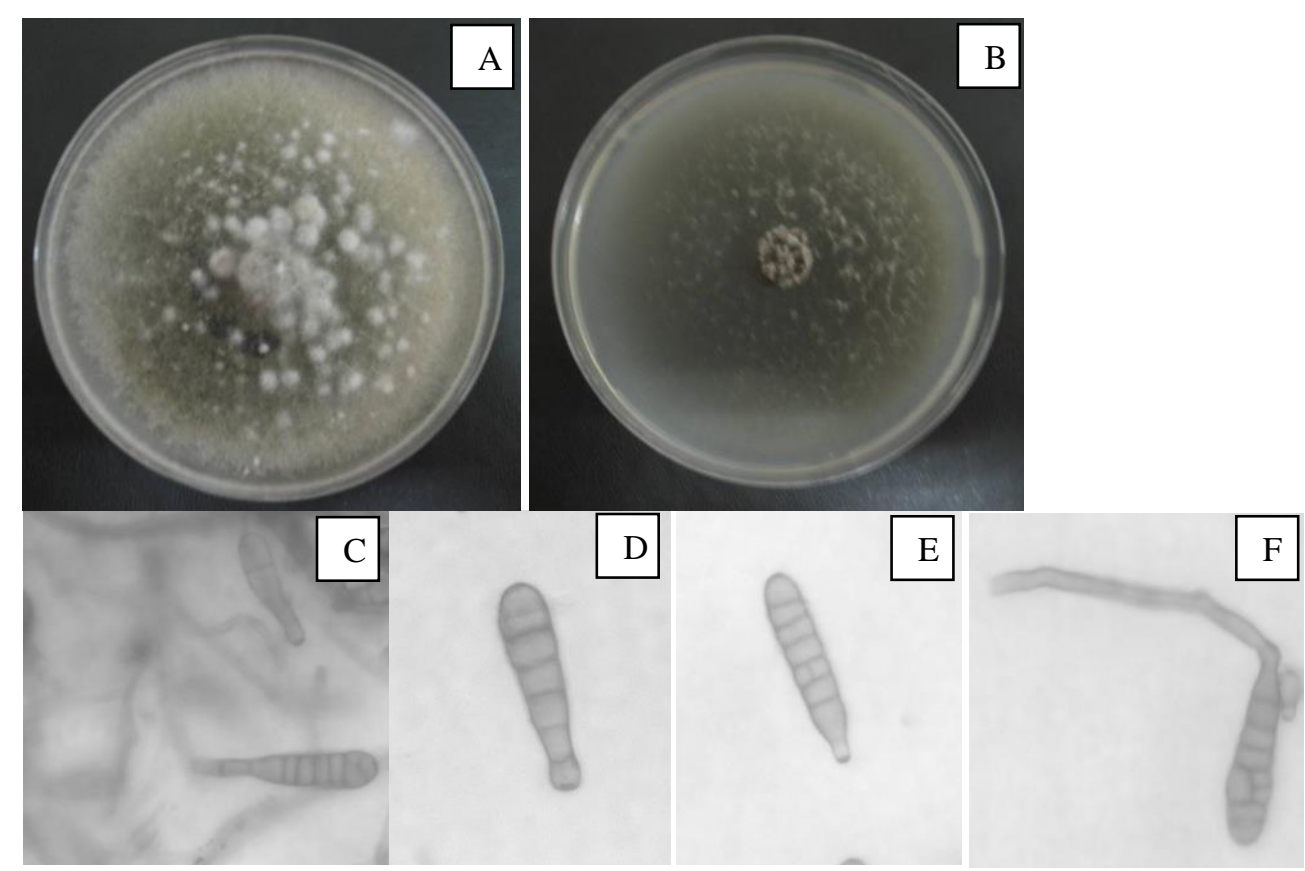

Şekil 4. Alternaria infectoria'nın PDA (A), PCA (B) besi ortamında koloni gelişimi ve konidileri $(\mathrm{C}, \mathrm{D}, \mathrm{E}, \mathrm{F})$

Arthrinium arundinis (Corda) Dyko \& B. Sutton (Syn: Apiospora montagnei Sacc; eşeyli formu: Gymnosporium arundinis Corda) PDA besi ortamında açık sarı-kül renginde pamuksu şekilde gelişmiş (Şekil 5A), MEA besi ortamında ise krem rengi bir gelişme, PCA besi ortamında ise koyu gri renkte bir gelişme (Şekil 5B) göstermiştir. 7 günlük inkübasyon sonucunda, gelişme hızları PDA besi ortamında $1.14 \mathrm{~cm} /$ gün ile önemli derecede hılı gelişmiştir $(\mathrm{P}=0.05)$. PCA besi ortamındaki gelişme hızı $1.02 \mathrm{~cm} /$ gün, MEA besi ortamında ise $1.02 \mathrm{~cm} /$ gün olarak belirlenmiştir. Etmenin konidileri bölmesiz, yuvarlak şekilli, koyu kahverengi rengindedir (Şekil 5C). Konidi büyüklüğü $6.25 \pm 0.73 \mu \mathrm{m}$ çapında belirlenmiştir. Etmenin BLAST analizi sonucunda Gen Bankasında bulunan çok sayıda $A$. arundinis izolatlar1 (Örnek Accession No: AB470870.1, HQ380772.1, KX533933.1) ile \%99 oranında benzer bulunmuştur. 

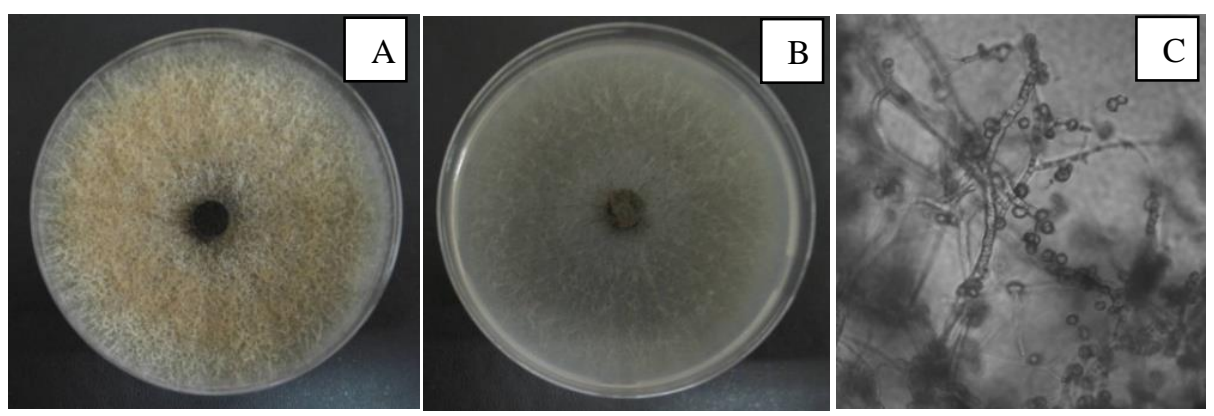

Şekil 5. Arthrinium arundinis'in PDA (A) ve PCA (B) besi ortamındaki koloni gelişimi ve konidileri (C)

Alternaria türlerinin tanılanması oldukça karmaşıktır. Daha önce de belirtildiği gibi son yıllarda 24 farklı seksiyona ayrılarak her seksiyonda yer alan tür grupları belirlenmiştir. Kanola tohumlarından izole ettiğimiz A. alternata alternata seksiyonu ve alternata tür grubu içinde, A. ethzedia ve A. infectoria infectoriae seksiyonunda infectoria tür grubu içinde bulunmaktadır (Woudenberg et al. 2013, Lawrence et al. 2013, Lawrence et al. 2014).

Bunlar arasında özellikle A. ethzedia ve A. infectoria' nın genetik olarak birbirine çok benzediği tespit edilmiş olup bu konudaki çalışmalar devam etmektedir (Dube 2014).

$\mathrm{Bu}$ çalışmada elde edilen sonuçlara göre Trakya Bölgesi kanola ekim alanlarından elde edilen tohumlarda tespit edilen Alternaria alternata, Alternaria ethzedia, A. infectoria ve Arthrinium arundinis'in bulunma oranları çok yüksek olmasa da, tohumlarda bazı izolatların \%60-80'lere varan hastalık şiddeti oluşturdukları görülmüştür. $\mathrm{Bu}$ nedenle hastalık etmenlerinin taşınmasını engellemek amacıyla kültürel önlem olarak ekimde kullanılacak tohumlukların söz konusu fungusların varlığ 1 açısından test edilmesi gerekmektedir. Tespit edilen hastalık etmenlerine karşı dayanıklılığın belirlenmesi incelenmesi gereken bir konudur. Ayrıca Alternaria türlerinin mikotoksin oluşturduğu dikkate alındığında bu konuda araştırmalar yapılması yararlı olacaktır. 


\section{KAYNAKLAR}

Anonim 2017. http://tuikapp.tuik.gov.tr/bitkiselapp/bitkisel.zul. (Erişim tarihi: 25.01.2017).

Brazauskiene I. and Petraitiene E. 2006. The occurrence of Alternaria blight (Alternaria spp.) and Phoma stem canker (Phoma lingam) on oilseed rape in central Lithuania and pathogenic fungi on harvested seed. Journal of Plant Protection Research, 46 (3), 295-311.

Chen G. Y., Wu C. P., Li B., Su H., Zhen S. Z. and An Y. L. 2010. Detection of Leptosphaeria maculans from important canola seeds. Journal of Plant Diseases and Protection, 117 (4), 173-176.

Clear R. M. 1992. Frequency and distribution of seedborne fungal pathogens in western Canadian canola-1989 and 1990. Canadian Plant Disease Survey, 72 (1), 21-27.

Clear R. M. and Patrick S. K. 1995. Frequency and distribution of seedborne fungi infecting canola seed from Ontario and western Canada - 1989 to 1993. Canadian Plant Disease Survey 75 (1), 9-17.

Damgacı E. ve Yılmaz R. 2016. Trakya Bölgesinde kanola Phoma (Leptosphaeria maculans, anamorf; Phoma lingam) hastalığının yayılışı, tanımı ve verim bileşenleri üzerine etkisi. Uluslararası Katılımlı Türkiye VI. Bitki Koruma Kongresi Bildirileri, 5-8 Eylül 2016 Konya, 495.

Domsch K.H., Gams W. and Anderson T.H. 1980: Compendium of Soil Fungi. London, Academic Press, New York, 859 p.

Dube J.P. 2014. Characterization of Alternaria alternata isolates causing brown spot of potatoes in South Africa. Master tezi, Pretoria Üniversitesi, Pretoria, 97s.

Dugan F. M. and Lupien S. L. 2002. Filamentous fungi quiescent in seeds and culm nodes of weedy and forage grass species endemic to the Palouse Region of Washington and Idaho. Mycopathologia, 156: 31-40.

Ellis M. B. 1976. Dematiaceous, Hyphomycetes. Commonwealth Mycological Institute, Kew, Surrey, England, 507 pp.

Gannibal P. B. 2008. Species of the genus Alternaria in cereal seeds in Russia. Mikologiya I Fitopatologiya, 42: 359-368.

Grey W. E. and Sands D.C. 1992. First Report of Arthrinium arundinis causing kernel blight on barley. Plant Disease, 76: 1077.

Gül M. K., Egesel C.Ö., Tayyar Ş. ve Mert Türk F. 2005. Kışlık kolza çeşitlerinde tohum ve tohum kalitesi ile ilgili bazı özelliklerin incelenmesi ve yetiştirme olanakları. Türkiye VI. Tarla Bitkileri Kongresi, 5-9 Eylül Antalya, 229-231.

Karman M. 1970. Bitki Koruma Araştırmalarında Genel Bilgiler. Denemelerin Kuruluşu ve Değerlendirme Esasları. Tarım Bakanlığg Zirai Mücadele ve Zirai Karantina Genel Müdürlüğü Yayınları, Mesleki Kitaplar Serisi, 278 s.

Kosiak B., Torp M., Skjerve E. and Andersen B. 2004. Alternaria and Fusarium in Norwegian grains of reduced quality- a matched pair sample study. International Journal of Food Microbiology, 93, 51-62. 
Lawrence D. P., Gannibal P. B., Peever T. L. and Pryor B. M. 2013. The sections of Alternaria: formalizing species-group concepts. Mycologia, 105. 530-546.

Lawrence D. P., Gannibal P. B., Dugan F. M. and Pryor B. M 2014. Characterization of Alternaria isolates from the infectoria species-group and a new taxon from Arrhenatherum, Pseudoalternaria arrhenatheria sp. nov. Mycological Progress, 13, 256-276.

Mankeviciene A., Suproniene S., Brazauskiene I. and Gruzdeviene E. 2011. Natural occurrence of Fusarium mycotoxins in oil crop seed. Plant Breeding and Seed Science, 63, 109-116.

Meena P. D., Awasthi R. P., Chattopadhyay C., Kolte S. J. and Kumar A. 2010. Alternaria blight: a chronic disease in rapeseed-mustard. Journal of Oilseed Brassica, 1 (1), 111 .

Noelting M. C., Molina M. C., Monaco C. I., Sandoval M. C. and Perello A. 2012. First report of Alternaria infectoria on amaranth (Amaranthus caudatus ssp. mantegazzianus) in Argentina. New Disease Reports, 25, 11.

Oviedo M. S., Ramirez M. L., Barros G. G. and Chulze S. N. 2011. Influence of water activity and temperature on growth and mycotoxin production by Alternaria alternata on irradiated soya beans. International Journal of Food Microbiology, 149, 127-132.

Özer G. ve Bayraktar H. 2015. Determination of fungal pathogens associated with Cuminum cyminum in Turkey. Plant Protection Science, 51 (2), 74-79.

Perello A., Moreno M. and Sisterna M. 2008. Alternaria infectoria species-group associated with black point of wheat in Argentina. Plant Pathology, 57, 379.

Perello A. E. and Larran S. 2013. Nature and effect of Alternaria spp. complex from wheat grain on germination and disease transmission. Pakistan Journal of Botany, 45 (5), 1817-1824

Tohyama A. and Tsuda M. 1995. Alternaria on cruciferous plants. 4. Alternaria species on seed of some cruciferous crops and their pathogenicity. Mycoscience, 36 (3), 257261.

Vinas I., Palma J., Garza S., Sibilia A., Sanchis V. and Visconti A. 1994. Natural occurrence of aflatoxin and Alternaria mycotoxins in oilseed rape from Catalonia (Spain): incidence of toxigenic strains. Mycopathologia, 128 (3), 175-179.

Visconti A., Sibilia A. and Sabia C. 1992. Alternaria alternata from oilseed rape; mycotoxin production and toxicity to Artemia salina larvae and rape seedlings. Mycotoxin Research, 8 (1): 9-16

Watanabe T. 2002. Pictorial atlas of soil and seed fungi, morphologies of cultured fungi and key to species. CRC Press, Florida, 486 pp.

Woudenberg J. H. J., Groenewald J. Z., Binder M. and Crous P.W. 2013. Alternaria redefined. Studies in Mycology, 75: 171-212. 